\title{
PENGARUH HARGA, DESAIN, SERTA KUALITAS PRODUK TERHADAP KEPUASAN KONSUMEN
}

\section{THE EFFECT OF PRICES, DESIGN, AND PRODUCT QUALITY ON THE CONSUMER SATISFACTION}

\author{
Arini Isfahila, Feti Fatimah, Wahyu Eko S \\ Fakultas Ekonomi Universitas Muhammadiyah Jember \\ E-mail : isfahilaarini@gmail.com, fetifatimah@unmuhjember.ac.id, \\ setianingsih@unmuhjember..ac.id
}

\begin{abstract}
ABSTRAK
Penelitian ini dilakukan pada pelanggan Umah Batik Banyuwangi. Penelitian ini bertujuan untuk mengetahui pengaruh harga, desain, dan kualitas produk Umah Sayu Wiwit Banyuwangi. Dalam penelitian ini data dikumpulkan dengan alat bantu berupa observasi, wawancara dan kuesioner terhadap 95 responden dengan teknik purpossive sampling, yang bertujuan untuk mengetahui persepsi responden terhadap masing-masing variabel. Analisis yang digunakan meliputi uji instrumen data (uji validitas, dan uji reliabilitas), analisis regresi linear berganda, uji asumsi klasik (uji normalitas, uji multikolinearitas, dan uji heteroskedastisitas, dan uji hipotesis (uji t koefisien determinasi). Dari hasil analisis menggunakan regresi dapat diketahui bahwa variabel harga, desain dan kualitas produk, semuanya berpengaruh signifikan terhadap kepuasan konsumen. Dari uji t diperoleh hasil harga, desain dan kualitas produk, semuanya berpengaruh signifikan terhadap kepuasan konsumen.
\end{abstract}

Kata Kunci: harga, desain, kualitas produk dan kepuasan konsumen

\begin{abstract}
This research was conducted on customer of Umah Sayu Wiwit Banyuwangi. This study aims to determine the effect of price, design, and to product quality Umah Sayu Wiwit Banyuwangi. In this research the data collected by means of aids in the form of observation, interview and questionnaire to 95 respondents with purposive sampling technique, which aims to know the perception of respondents to each variable. The analysis used included data instrument test (validity test and reliability test), multiple linear regression analysis, classical assumption test (normality test, multicollinearity test, and heteroscedasticity test, and hypothesis test ( $\mathrm{t}$ test, coefficient of determination ). From the results of analysis using regression can be seen that price variables, design and product quality, all have a significant effect on customer satisfaction. From $t$ test, price, design and product quality, all have a significant effect on customer satisfaction.
\end{abstract}

Keywords: price, designy, product quality and customer satisfaction 


\section{PENDAHULUAN}

Batik kini mendapatkan tempat dihati masyarakat Indonesia dan juga masyarakat internasional, dengan coraknya yang indah batik dengan sangat mudah memikat hati masyarakat dunia dan juga peminatnya semakin bertambah di dunia internasional. Di Indonesia batik dibuat diberbagi daerah, terutama dipulau jawa. Batik adalah kerajinan yang memiliki nilai seni budaya Indonesia (khususnya Jawa) sejak jaman dahulu. Saat ini batik bahkan menjadi warisan budaya asli Indonesia yang sudah diakui dunia internasional. Masing-masing wilayah di Indonesia memiliki batik khas tersendiri yang semakin menjadi beranekaragam jenis dan motif batiknya. Perkembangan batik di berbagai wilayah kabupaten/kota di Jawa Timur saat ini cukup signifikan. Ini ditandai dengan bermunculnya industri skala ini mikro kecil maupun skala rumah tangga yang terus menghasilkan produk dengan motif dan pewarnaan khas yang dipengaruhi oleh karakter daerah masing-masing.

Masih dapat bertahannya seni batik sampai saat ini tidak dapat dilepaskan dari adanya rasa kebangsaan dan usaha untuk melestarikan pemakain batik dalam bentuk busana tradisional maupun busana masa kini, memang dalam kenyataannya beberapa daerah penghasil batik telah mengurangi kegiatannya, bahkan diantara mereka ada yang yang tidak lagi sebagai daerah penghasil batik. Mereka telah tertarik dibidang usaha yang dianggapnya telah memberikan keuntungan dan masa depan yang lebih baik. Mengangkat kekayaan desain, motif serta pewarnaan dari bahan alam, perajin batik Jawa Timur bertekad menjadikan batik Jawa Timur mendunia. Sebanyak 300 perajin batik asal Jawa Timur membentuk organisasi yang diberi nama asosiasi perajin batik Jawa Timur, sebagai wadah pengembangan industri kerajinan tangan dan kreatif asli Indonesia agar bisa bersaing di pasar global. Sebanyak 1.120 motif batik dari 38 kabupaten dan kota di Jawa Timur siap dikembangkan, untuk menjadikan Batik sebagai industri kreatif yang semakin dikenal dan diminati di dunia. Daerah Ponorogo pada awal abad XX juga dikenal sebagai daerah batik yang dalam pewarnaannya menggunakan nila yang tidak luntur. Akibat batik cap kasar diproduksi secara massal yang dikenal dengan batik cap mori biru, pasaran batik cap kasar Ponorogo terkenal seluruhIndonesia. Mojokerto, Jombang, Tulungagung, dan Ponorogo yang tidak begitu dikenal dalam peta industri batik, sampai sekarang masih ada sisa jejak kerajinan batik. Batik masih berkembang di 
Sidoarjo, Madura, Tuban, Blitar, Banyuwangi dan daerah-daerah lainnya. Batik Madura, memiliki ciri khas dengan motif batik pantai dengan warna cenderung gelap, merah gelap, bahkan dipadukan dengan warna hitam yang merupakan warna yang disukai oleh masyarakat Madura. Batik Sidoarjo menampilkan motif udang dan ikan serta dedaunan; tapi juga menampilkan warna gelap. Sementara batik Surabaya lebih mengarah pada motif bebas imprisonis meski tetap natural dengan warna-warna terang, abu-abu atau coklat cerah.

Kepuasan konsumen biasanya terjadi apabila konsumen merasa senang dan cocok dengan produk yang dipakai. kepuasan konsumen merupakan suatu perasaan konsumen yang membandingkan antara apa yang dia terima dan yang diharapkan. Umpan balik pasar secara volunter seperti komentar tertentu yang tidak diminta, survey pelanggan, riset pasar, dan forum diskusi pemantauan online. Peningkatan kepuasan pelanggan sangat dibutuhkan dalam persaingan pasar semakin tajam. Cannon (2008: 504) kepuasan konsumen adalah tingkat dimana perusahaan dapat memenuhi harapan, hasrat, dan kebutuhan konsumen. Tjiptono (2012:146) kepuasan pelanggan adalah perasaan senang atau kecewa seseorang yang muncul setelah membandingkan antara persepsi terhadap kinerja (hasil) suatu produk dengan harapan-harapanya. Hasil penelitian Tristiana (2016). Iriyanti, dkk (2016) kepuasan konsumen jika kinerja sesuai dengan ekspektasi, pelanggan akan puas. kepuasan konsumen mencangkup perbedaan antara harapan dan kinerja atau hasil yang diharapkan. Oktaviani (2016) sebagai respon pelanggan terhadap ketidaksesuaian antara tingkat kepentingan sebelumnya dan kinerja aktual yang dirasakan setelah pemakaian. Anggriana, dkk (2017) kepuasan konsumen mencakup perbedaan antara harapan dan hasil yang diharapkan. Tajab (2017) Kepuasan konsumen merupakan komponen penting yang mempengaruhi keberlanjutan pertumbuhan dan laba perusahaan. Pranata (2017) kepuasan konsumen adalah harapan, kesesuain dan juga kecocokan produk dengan hati para konsumen. Mayasari (2011) bahwa Konsumen tidak lagi membeli produk sekedar berdasarkan pertimbangan wujud fisik saja, namun juga termasuk segala aspek pelayanan yang melekat pada produk, mulai dari tahap pembelian sampai pada tahap pasca pembelian. Banyak faktor yang dapat mempengaruhi kepuasan konsumen diantaranya harga,desain dan kualitas produk. 
Harga dapat menunjukan kualitas merek dari suatu produk, dimana konsumen mempunyai anggapan bahwa harga yang mahal biasanya mempunyai kualitas yang baik. Kotler dan Armstrong 2010:85 Harga adalah sejumlah uang yang ditukarkan untuk sebuah produk atau jasa. Lebih jauh lagi, harga adalah jumlah dari seluruh nilai yang konsumen tukarkan untuk jumlah manfaat dengan memiliki atau menggunakan suatu barang dan jasa. Menurut Kotler dan Keller (2009: 151) Harga adalah faktor positioning kunci dan harus diputuskan dalam hubungannya dengan pasar sasaran, bauran pilihan produk dan jasa dan juga persaingan. Menurut hasil penelitian Tristiana (2016) Harga merupakan faktor penentu yang mempengaruhi pilihan pembelian pada bahan-bahan pokok sehari-hari. Namun dalam dasawarsa terakhir ini, faktor-faktor lain selain harga telah beralih menjadi relatif lebih penting dalam proses pembelian. Iriyanti, dkk (2016) Bagi konsumen harga merupakan faktor yang menentukan dalam pengambilan keputusan untuk membeli suatu produk atau tidak. Pranata (2017) harga adalah sesuatu barang yang mempunyai nilai atau jumlah yang bisa ditukarkan kepada konsumen dan memberikan manfaat tertentu.

Desain adalah dimensi yang unik. Dimensi ini banyak menawarkan aspek emosional dalam mempengaruhi kepuasan pelanggan. Memilih desain haruslah pula dihubungkan dengan tujuan memperoleh laba didalam jangka panjang. Kotler dan Keller (2012:10) Bagi pelanggan, produk yang dirancang dengan baik adalah produk yang penampilannya menyenangkan dan mudah dibuka, dipasang, digunakan, diperbaiki, dan disingkirkan. Desainer harus memperhitungkan semua faktor ini. (Kotler dan Keller,2009:10) ketika persaingan semakin kuat, desain menawarkan satu cara potensial untuk mendiferensiasikan serta memposisikan produk dan jasa perusahaan. Tajab (2017) desain adalah totalitas fitur yang mempengaruhi tampilan, rasa, dan fungsi produk berdasarkan kebutuhan pelanggan. Pranata (2017) bahwa semakin bagus desain semakin banyak masyarakat berminat untuk membeli produk tersebut, sehingga perusahaan harus memperhatikan desain sesuai kebutuhan masyarakat.

Kualitas produk Perusahaan berusaha fokus pada kualitas produk yang dimiliki dan membandingkannya dengan produk yang ditawarkan oleh perusahaan pesaing. Kotler (2005:49) Kualitas produk keseluruhan ciri serta dari suatu produk atau pelayanan pada kemampuan untuk memuaskan kebutuhan yang dinyatakan/tersirat. Nasution (2005:3) kualitas produk adalah suatu kondisi dinamis yang berhubungan dengan produk, 
manusia/tenaga kerja, proses dan tugas, serta lingkungan yang memenuhi atau melebihi harapan konsumen. Tjiptono (2006:299) mendefinisikan kualitas sebagai tingkat mutu yang diharapkan dan pengendalian keragaman dalam mencapai mutu tersebut untuk memenuhi kebutuhan konsumen. Menurut hasil penelitian Oktaviani (2016) bahwa kualitas produk merupakan pemahaman bahwa produk merupakan peluang yang ditawarkan oleh penjual dan mempunyai nilai jual lebih yang tidak dimiliki oleh produk pesaing. Tristiana (2016) kualitas produk yaitu segala sesuatu yang ditawarkan kepada pangsa pasar agar diperhatikan, diminta, dipakai atau dikonsumsi sehingga memuaskan kebutuhan atau keinginan manusi. Iriyanti, dkk (2016) Apabila kualitas produk yang dihasilkan baik maka konsumen akan cenderung untuk melakukan pembelian ulang sedangkan bila kualitas produk tersebut tidak sesuai dengan yang diinginkan konsumen maka akan mengalihkan pembelian berikutnya pada produk lain yang sejenis.

Nama Sayu Wiwit merupakan nama pahlawan wanita banyuwangi yang kemudian digunakan sebagai nama dari sanggar batik tersebut. sejak awal didirikannya umah sayu wiwit pada tahun 1995, produksi batik hanya berupa batik tulis. Namun untuk mengantisipasi minimnya jumlah pembatik dan mempercepat waktu produksi, umah batik sayu siwit melakukan strategi dengan menambah alat batik cap agar hasil produksi batik dapat bertambah dalam waktu yang relatif singkat. Batik cap diproduksi umah batik sayu wiwit sejak tahun 2000. Batik sayu wiwit didirikan pada tahun 1995 di J1. Sidopekso Kel. Temenggungan Banyuwangi. Batik sayu wiwit mempunyai desain-desain batik khas diantaranya asli motif tradisional batik Gajah Oling, yang terdiri dari ornamen gajah oling; ornamen daun dilem berjumlah tiga; ornamen Bunga Melati berkelopak lima; dan ornamen Manggar berjumlah tiga dll. Sejak awal produksi batik sayu wiwit hanya berupa batik tulis, batik cap, dan batik printing. Sayu Wiwit memiliki ijin usaha dengan No. SIUP: 0100/ 13-6/ PK/ III/ 1997, Batik Sayu Wiwit pada awalnya hanya memproduksi motif batik Gajah Oling. Motif batik Gajah Oling merupakan perpaduan antara gambar atau ornamen kupu-kupu, batang, daun, dan bunga melati. Motif batik Gajah Oling merupakan batik yang mempunyai tingkat kesulitan yang paling tinggi dalam proses pembuatannya. pada perkembangan selanjutnya, Sayu Wiwit menambah produksi motif batik tulis yaitu motif batik Kangkung Setingkes dan motif batik Paras Gempal.

Berdasarkan uraian diatas, maka diperoleh tujuan penelitian sebagai berikut: 
1. Untuk menguji dan menganalisa pengaruh harga terhadap kepuasan konsumen kain batik sayu wiwit di banyuwangi.

2. Untuk menguji dan menganalisa pengaruh desain terhadap kepuasan konsumen kain batik sayu wiwit di banyuwangi.

3. Untuk menguji dan menganalisa pengaruh kualitas produk terhadap kepuasan konsumen kain batik sayu wiwit di banyuwangi.

\section{TINJAUAN PUSTAKA}

\section{Harga}

Menurut Kotler dan Amstrong (2012:345) harga dapat didefenisikan secara sempit sebagai jumlah uang yang ditagihkan untuk suatu produk atau jasa. Atau dapat didefenisikan secara luas harga sebagai jumlah nilai yang ditukarkan konsumen untuk keuntungan memiliki dan menggunakan produk atau jasa yang memungkinkan perusahaan mendapatkan laba yang wajar dengan cara dibayar untuk nilai pelanggan yang diciptakannya. Harga menurut Kotler dan Armstrong (2010:85) adalah sejumlah uang yangditukarkan untuk sebuah produk atau jasa.Lebih jauh lagi, harga adalah jumlah dari seluruhnilai yang konsumen tukarkan untuk jumlah manfaat dengan memiliki atau menggunakansuatu barang dan jasa. Menurut Kotler dan Keller (2009: 151) harga adalah faktor positioning kunci dan harus diputuskan dalam hubungannya dengan pasar sasaran, bauranpilihan produk dan jasa dan juga persaingan. Harga (price) merupakan hasilkebijakan tentang penetapan harga produk (pricing strategy), meliputi daftarharga, diskon, periode pembayaran, jangka waktu kredit. Harga merupakan satuan biaya yang harus dikeluarkan oleh konsumen karena sudah menerima barang atau manfaat dari suatu produk atau jasa (Qomariah, 2016).

\section{Desain}

Desain adalah totalitas fitur yang mempengaruhi tampilan, rasa, dan fungsi produk berdasarkan kebutuhan konsumen. Desain sangat penting terutama dalam pembuatan dan pemasaran jasa eceran, busana, barang kemasan dan peralatan tahan lama. Desainer harus menemukan berapa banyak yang diinvestasikan dalam bentuk, pengembangan fitur, kinerja, kesesuaian, ketahanan, keandalan, kemudahan perbaikan dan gaya. Bagi perusahaan, produk yang dirancang dengan baik adalah produk yang penampilannya menyenangkan dan mudah dibuka, digunakan, diperbaiki dan 
disingkirkan (Kotler dan Keller, 2009: 10). Desain yang baik dimulai pemahaman mendalam tentang kebutuhan pelanggan.

\section{Kualitas Produk}

Nasution (2005:3) kualitas produk adalah suatu kondisi dinamis yang berhubungan dengan produk, manusia/tenaga kerja, proses dan tugas, serta lingkungan yang memenuhi atau melebihi harapan konsumen. Tjiptono (2006:299) mendefinisikan kualitas sebagai tingkat mutu yang diharapkan dan pengendalian keragaman dalam mencapai mutu tersebut untuk memenuhi kebutuhan konsumen. Produk yaitu segala sesuatu yang ditawarkan kepada pangsa pasar agar diperhatikan,diminta, dipakai atau dikonsumsi sehingga memuaskan kebutuhan atau keinginanmanusi.Istilah produk mempunyai bermacan-macam arti dan makna. Menurut Kotler(2011;47) Produk adalah segala sesuatu yang dapat ditawarkan ke pasar untuk menarik perhatian, pembelian atau dikonsumsi yang dapat memuaskan keinginan atau kebutuhan.

\section{Kepuasan Konsumen}

Menurut Kotler dan keller (2008: 139), menyatakan bahwa kepuasan konsumen adalah perasaan senang atau kecewa seseorang yang timbul karena adanya perbandingan kinerja yang berorientasi pada produk (atau hasil) terhadap ekspektasi mereka.Kepuasan pelanggan dapat diukur dengan berbagai cara antara lain: umpan balik pasar secara volunter seperti komentar tertentu yang tidak diminta, survey pelanggan, riset pasar, dan forum diskusi pemantauan online. Peningkatan kepuasan pelanggan sangat dibutuhkan dalam persaingan pasar yang semakin tajam. Tingkat kepuasan pelanggan tergantung pada kinerja yang dilakukan/diterima dari produk atau jasa serta standar yang digunakan pelanggan (Assauri, 2012: 11).

Kepuasan konsumen terjadi apabila konsumen sudah membeli produk tersebut dan merasa senang dengan apa yang sudah dinikmati mulai dari harga, desain dan fitur yang ada pada produk samsung. Menurut Cannon (2008: 504) kepuasan konsumen adalah tingkat dimana perusahaan dapat memenuhi harapan hasrat, dan kebutuhan konsumen. Hal ini dapat disimpulakan bahwa kepuasan konsumen adalah harapan, kesesuain dan juga kecocokan produk dengan hati para konsumen. 


\section{METODE PENELITIAN Desain Penelitian}

Dalam merancang suatu penelitian, dikenal penelitian ekploratoris dan konklusif, dimana penelitian konklusif dapat diklasifikasikan lagi atas penelitian diskriptif dan kausal. Jika dilihat dari variabelnya yaitu variabel bebas dan terikat, penelitian ini adalah penelitian kausalitas. Penelitian kausalitas bertujuan mengukur kekuatan hubungan antara dua variabel atau lebih, juga menunjukkan arah hubungan antara variabel bebas dan terikatnya. Dengan kata lain penelitian kausalitas mempertanyakan masalah sebab akibat (Kuncoro 2009).

\section{Populasi dan Sampel}

Populasi adalah gabungan dari seluruh elemen yang berbentuk peristiwa, hal atau orang yang memiliki karakteristik yang serupa yang menjadi pusat perhatian seorang peneliti karena itu dipandang sebagai sebuah semesta penelitian (Ferdinand, 2006). Populasi yang digunakan dalam penelitian ini adalah masyarakat di banyuwangi yang pernah membeli produk Kain batik sayu wiwit banyuwangi tersebut yang jumlahnya banyak, maka dilakukan pengambilan sampel untuk penelitian ini. Sampel dalam penelitian ini sebanyak 95 responden. Sugiyono (2008: 116), menjelaskan sampel adalah bagian dari jumlah dan karakteristik yang dimiliki oleh populasi tersebut. Sampel merupakan bagian dari populasi yang ada, sehingga untuk pengambilan sampel harus menggunakan cara tertentu yang didasarkan oleh pertimbangan-pertimbangan yang ada. Teknik pengambilan sampel yang digunakan dalam penelitian ini adalah purposive sampling, yaitu peneliti mempunyai pertimbangan-pertimbangan dan syarat-syarat tertentu.

\section{Uji Validitas}

Validitas didefinisikan sebagai ukuran seberapa kuat suatu alat tes melakukan fungsi ukurannya. Model pengujian menggunakan pendekatan Pearson Correlation untuk menguji validitas pernyataan kuesioner. Uji validitas digunakan untuk mengukur sah atau tidaknya suatu kuesioner.

\section{Uji Reliabilitas}

Apabila validitas telah diperoleh, maka peneliti harus mempertimbangkan pula pengukuran reliabilitas. Reliabilitas menunjukkan pada satu pengertian bahwa suatu 
instrumen cukup dapat dipercaya untuk digunakan sebagai alat pengumpul data karena instrumen tersebut sudah baik. Pengujian reliabilitas bertujuan untuk mengetahui konsistensi hasil pengukuran variabel-variabel.

\section{Analisis Data}

Alat analisis yang digunakan pada penelitian ini adalah regresi linear berganda. Berikut persamaan yang dibuat berdasarkan variabel yang digunakan dalam penelitian ini $: Y=a+b_{1} X_{1}+b_{2} X_{2}+b_{3} X_{3}+b_{4} X_{4}+b_{5} X_{5}+b_{6} X_{6}+b_{7} X_{7}+e$

Analisis data menggunakan uji instrumen data (uji validitas, dan uji reliabilitas), analisis regresi linear berganda, uji asumsi klasik (uji normalitas, uji multikolinearitas, dan uji heteroskedastisitas), dan uji hipotesis (uji t, koefisien determinasi).

\section{HASIL DAN PEMBAHASAN Uji Validitas}

Uji validitas digunakan untuk menguji sejauh mana ketepatan alat pengukur dapat mengungkapkan konsep gejala atau kejadian yang diukur. Item kuesioner dinyatakan valid apabila nilai $r$ hitung $>r$ table $(n-2)$ dan nilai signifikasi $<0,05$.

Tabel 1. Hasil Uji Validitas

\begin{tabular}{|c|c|c|c|c|c|c|}
\hline \multicolumn{2}{|c|}{ Variabel/ Indikator } & \multicolumn{2}{|c|}{ Kriteria 1} & \multicolumn{3}{|c|}{ Kriteria 2} \\
\hline$\overline{\text { No }}$ & Harga & r hitung & $\mathrm{r}$ table & Nilai sig & Alpha & Keterangan \\
\hline 1 & $\mathrm{X} 1.1$ & 0,909 & 0,2017 & 0,000 & 0,05 & Valid \\
\hline 2 & $\mathrm{X} 1.2$ & 0,589 & 0,2017 & 0,000 & 0,05 & Valid \\
\hline 3 & $\mathrm{X} 1.3$ & 0,669 & 0,2017 & 0,000 & 0,05 & Valid \\
\hline \multirow[t]{2}{*}{4} & $\mathrm{X} 1.4$ & 0,919 & 0,2017 & 0,000 & 0,05 & Valid \\
\hline & Desain & & & & & \\
\hline 1 & $\mathrm{X} 2.1$ & 0,647 & 0,2017 & 0,000 & 0,05 & Valid \\
\hline 2 & $\mathrm{X} 2.2$ & 0,830 & 0,2017 & 0,000 & 0,05 & Valid \\
\hline \multirow[t]{2}{*}{3} & $\mathrm{X} 2.3$ & 0,852 & 0,2017 & 0,000 & 0,05 & Valid \\
\hline & Kualitas Produk & & & & & \\
\hline 1 & X3.1 & 0,587 & 0,2017 & 0,000 & 0,05 & Valid \\
\hline 2 & X3.2 & 0,730 & 0,2017 & 0,000 & 0,05 & Valid \\
\hline 3 & X3.3 & 0,648 & 0,2017 & 0,000 & 0,05 & Valid \\
\hline 4 & X3.4 & 0,664 & 0,2017 & 0,000 & 0,05 & Valid \\
\hline 5 & X3.5 & 0,673 & 0,2017 & 0,000 & 0,05 & Valid \\
\hline 6 & X3.6 & 0,711 & 0,2017 & 0,000 & 0,05 & Valid \\
\hline 7 & X3.7 & 0,700 & 0,2017 & 0,000 & 0,05 & Valid \\
\hline \multirow[t]{2}{*}{8} & $\mathrm{X} 3.8$ & 0.706 & 0,2017 & 0,000 & 0,05 & Valid \\
\hline & $\begin{array}{l}\text { Kepuasan } \\
\text { Konsumen }\end{array}$ & & & & & \\
\hline 1 & Y1 & 0,684 & 0,2017 & 0,000 & 0,05 & Valid \\
\hline 2 & $\mathrm{Y} 2$ & 0,756 & 0,2017 & 0,000 & 0,05 & Valid \\
\hline 3 & Y3 & 0,840 & 0,2017 & 0,000 & 0,05 & Valid \\
\hline 4 & Y4 & 0,801 & 0,2017 & 0,000 & 0,05 & Valid \\
\hline
\end{tabular}

Sumber: Data Diolah. 
Berdasarkan hasil uji validitas diketahui bahwa seluruh nilai sig lebih kecil daripada 0,05, sehingga kuesioner yang digunakan dinyatakan valid.

\section{Uji Reliabilitas}

Uji reliabilitas digunakan untuk mengukur suatu kuesioner yang merupakan indikator dari variabel. Suatu kuesioner dinyatakan reliabel atau handal jika jawaban seseorang terhadap pernyataan adalah konsisten atau stabil dari waktu ke waktu.

Tabel 2. Hasil Uji Reliabilitas

\begin{tabular}{clccl}
\hline No & \multicolumn{1}{c}{ Variabel } & $\begin{array}{c}\text { Alpha } \\
\text { hitung }\end{array}$ & $\begin{array}{c}\text { Standar } \\
\text { alpha }\end{array}$ & Keterangan \\
\hline $\mathbf{1}$ & Harga $\left(\mathrm{X}_{1}\right)$ & 0,810 & 0,600 & Reliabel \\
$\mathbf{2}$ & Desain $\left(\mathrm{X}_{2}\right)$ & 0,818 & 0,600 & Reliabel \\
$\mathbf{3}$ & Kualitas produk $\left(\mathrm{X}_{3}\right)$ & 0,766 & 0,600 & Reliabel \\
$\mathbf{4}$ & Kepuasan konsumen $(\mathrm{Y})$ & 0,804 & 0,600 & Reliabel \\
\hline
\end{tabular}

Sumber: Data Diolah.

Hasil uji reliabilitas tersebut menunjukkan bahwa semua variabel mempunyai koefisien alpha yang cukup atau memenuhi criteria untuk dikatakan reliable yaitu > 0,600, sehingga untuk selanjutnya item-item pada masing-masing konsep variabel tersebut layak digunakan sebagai alat ukur.

\section{Analisis Regresi Linear Berganda}

Analisis regresi digunakan untuk menguji hipotesis tentang pengaruh secara signifikan variabel bebas terhadap variabel terikat.

Tabel 3. Hasil Regresi Linear Berganda

\begin{tabular}{clc}
\hline No & Variabel & Koefisien Regresi \\
\hline $\mathbf{1}$ & Konstanta & 1.048 \\
$\mathbf{2}$ & Harga $\left(\mathrm{X}_{1}\right)$ & 0,188 \\
$\mathbf{3}$ & Desain $\left(\mathrm{X}_{2}\right)$ & 0,364 \\
$\mathbf{4}$ & Kualitas produk $\left(\mathrm{X}_{3}\right)$ & 0,506 \\
\hline
\end{tabular}

Sumber: Data Diolah.

Berdasarkan tabel 3. dapat diketahui persamaan regresi yang terbentuk adalah :

$\mathrm{Y}=1.048+0,188 \mathrm{X}_{1}+0,364 \mathrm{X}_{2}+0,506 \mathrm{X}_{3}$

Nilai koefisien ketiga variabel menunjukkan jika nilai variabel kepuasan konsumen meningkat sebesar satu satuan. Nilai koefisien tersebut juga mengindikasikan bahwa 
ketiga variabel memiliki pengaruh signifikan terhadap kepuasan konsumen, artinya jika ketiga variabel semakin baik maka kepuasan konsumen Umah Batik Sayu Wiwit Banyuwangi akan semakin meningkat.

\section{Uji Hipotesis}

Pengujian dilakukan dengan melihat statistic $\mathrm{t}$ hitung dengan statistik $\mathrm{t}$ tabel dan taraf signifikasi ( $p$-value), jika taraf signifikasi yang dihasilkan dari perhitungan dibawah 0,05 maka hipotesis diterima, sebaliknya jika taraf signifikasi hasil hitung lebih besar dari 0,05 maka hipotesisi ditolak.

Tabel 4. Hasil Uji t

\begin{tabular}{llccccc}
\hline No & Variabel & $\begin{array}{c}\text { Signifikansi } \\
\text { Hitung }\end{array}$ & $\begin{array}{c}\text { Taraf } \\
\text { Signifkansi }\end{array}$ & $\mathrm{t}_{\text {hitung }}$ & $\mathrm{t}$ tabel & Keterangan \\
\hline $\mathbf{1}$ & Harga & 0,002 & 0,05 & 3,723 & 1,6618 & Signifikan \\
$\mathbf{2}$ & Desain & 0,002 & 0,05 & 3,123 & 1,6618 & Signifikan \\
$\mathbf{3}$ & Kualitas produk & 0,000 & 0,05 & 8,465 & 1,6618 & Signifikan \\
\hline
\end{tabular}

Sumber: Data Diolah.

\section{Uji Koefisien Determinasi $\left(\mathbf{R}^{2}\right)$}

Koefisien determinasi merupakan besaran yang menunjukkan besarnya variasi variabel dependen yang dapat dijelaskan oleh variabel independennya

Tabel 5. Hasil Uji Koefisien Determinasi

\begin{tabular}{clc}
\hline No & Kriteria & Koefisien \\
\hline $\mathbf{1}$ & $R$ & 0,887 \\
$\mathbf{2}$ & $R$ Square & 0,787 \\
$\mathbf{3}$ & Adjusted $R$ Square & 0,780 \\
\hline
\end{tabular}

Sumber: Data Diolah.

Dari tabel 5. diketahui hasil perhitungan regresi bahwa koefisien determinasi yang diperoleh sebesar 0,780. Hal ini berarti 78\% variasi variabel loyalitas pelanggan dapat dijelaskan oleh harga, desain dan kualitas produk, sedangkan sisanya sebesar 0,22 atau $22 \%$ diterangkan oleh variabel lain yang tidak diajukan dalam penelitian ini 


\section{PEMBAHASAN}

Secara nyata berdasarkan hasil penelitian menunjukkan bahwa secara statistik kedua hipotesis yang diajukan terdukung oleh teori sebelumnya. Dari data pada pengujian hipotesis sebelumnya. Berdasarkan hasil pengujin secara statistik, penjelasan dari masing-masing pengaruh variabel dijelaskan sebagai berikut :

\section{Pengaruh Harga Terhadap Kepuasan konsumen.}

Dengan taraf signifikasi 0,002 atau lebih kecil dari 0,05 maka variabel harga dipertahankan guna meningkatkan kepuasan konsumen. Semakin menarik harga yang ditawarkan Umah Batik Sayu Wiwiwt akan meningkatkan kepuasan konsumen. Artinya bahwa harga yang meliputi : Keterjangkauan harga, Kesesuaian harga dengan kualitas produk, Daya saing harga, Kesesuaian harga dengan manfaat berpengaruh terhadap kepuasan konsumen. Hasil ini mendukung teori indikator yang dikemukakan oleh Kotler dan Amstrong (2012: 52). Hasil ini juga mendukung penelitian sebelumnya Mayasari (2011) menyatakan bahwa harga berpengaruh signifikan terhadap kepuasan konsumen. Iriyanti, dkk (2016) menyatakan harga berpengaruh signifikan terhadap kepuasan. Tristiana (2016) menyatakan harga berpengaruh signifikan terhadap kepuasan konsumen Tajab (2017) menyatakan harga berpengaruh signifikan terhadap kepuasan konsumen. Anggriana, dkk (2017) menyatakan harga berpengaruh terhadap kepuasan pelanggan. Pranata (2017) menyatakan bahwa harga berpengaruh signifikan terhadap kepuasan konsumen. Dan sesuai dengan hipotesis yang diajukan, yaitu harga berpengaruh terhadap kepuasan konsumen. Untuk menganalisis data, penelitian ini menggunakan alat analisis regresi linier berganda. Hasil dari penelitian ini menunjukkan bahwa variabel harga berpengaruh signifikan terhadap kepuasan konsumen.

\section{Pengaruh Desain Terhadap Kepuasan Konsumen.}

Dengan taraf signifikasi 0,002 atau lebih kecil dari 0,05 maka variabel desain dipertahankan guna meningkatkan kepuasan konsumen. Semakin menarik desain yang dibuat oleh Umah Batik Sayu Wiwit akan meningkatkan kepuasan konsumen. Artinya desain yang meliputi : desain warna, ukuran, dan bahan-bahan. Hasil ini mendukung teori indikator yang dikemukakan oleh Stringer dan C. Dennis (2015: 20). Hasil ini juga mendukung penelitian sebelumnya Tajab (2017) yang menyatakan pengaruh desain 
terhadap kepuasan konsumen. Pranata (2017) menyatakan bahwa Desain berpengaruh signifikan terhadap kepuasan konsumen. dan sesuai dengan hipotesis yang diajukan, yaitu desain berpengaruh terhadap kepuasan konsumen. Untuk menganalisis data, penelitian ini menggunakan alat analisis regresi linier berganda. Hasil dari penelitian ini menunjukkan bahwa variabel desain berpengaruh dan signifikan terhadap kepuasan konsumen.

\section{Pengaruh Kualitas Produk Terhadap Kepuasan Konsumen.}

Dengan taraf signifikasi 0,000 atau lebih kecil dari 0,05 maka variabel desain dipertahankan guna meningkatkan kepuasan konsumen. Semakin baik kualitas produk yng ditawarkan Umah Batik Sayu Wiwit akan meningkatkan kepuasan konsumen. Artinya bahwa kualitas poduk yang meliputi : kinerja, keistimewaan, keandalan, kesesuaian dengan spesifikasi, daya tahan, kemampuan pelayanan, estetika dan persepsi terhadap kualitas. Hasil ini mendukung teori indikator yang dikemukakan oleh Tjiptono (2015:78). Hasil ini juga mendukung penelitian sebelumnya Mayasari (2011) menyatakan bahwa kualitas produk berpengaruh signifikan terhadap kepuasan konsumen. Oktaviani (2016) menyatakan bahwa kualitas produk berpengaruh signifikan terhadap kepuasan konsumen. Iriyanti dkk (2016) menyatakan bahwa kualitas produk berpengaruh terhadap kepuasan pelanggan. Tristiana (2016) menyatakan bahwa kualitas produk berpengaruh signifikan terhadap kepuasan konsumen. Tajab (2017) menyatakan bahwa kualitas produk berpengaruh terhdap kepuasan konsumen. Dan sesuai dengan hipotesis yang diajukan, yaitu kualitas produk berpengaruh terhadap kepuasan konsumen. Untuk menganalisis data, penelitian ini menggunakan alat analisis regresi linier berganda. Hasil dari penelitian ini menunjukkan bahwa variabel kualitas produk berpengaruh dan signifikan terhadap kepuasan konsumen.

\section{KESIMPULAN DAN SARAN}

\section{Kesimpulan}

Dari pengujian secara statistic yang telah dilakukan, maka dapat ditarik kesimpulan sebagai berikut:

1. Harga berpengaruh secara signifikan terhadap kepuasan konsumen Umah Batik Sayu Wiwit. Hal ini berarti semakin baik harga yang diberikakan perusahaan kepada pelanggan maka akan meningkatkan kepuasan konsumen terhadap Umah Batik Sayu Wiwit. 
2. Desain berpengaruh secara signifikan terhadap kepuasan konsumen Umah Batik Sayu Wiwit. Hal ini berarti semakin baik desain yang diberikan perusahaan kepada pelanggan maka akan meningkatkan kepuasan konsumen Umah Batik Sayu Wiwit.

3. Kualitas produk berpengaruh secara signifikan terhadap kepuasan konsumen Umah Batik Sayu Wiwit. Hal ini berarti semakin baik kualitas produk yang diberikan perusahaan kepada pelanggan maka akan meningkatkan kepuasan konsumen Umah Batik Sayu Wiwit.

\section{Saran}

Berdasarkan dari hasil penelitian yang didapat maka saran yang bisa disampaikan dalam penelitian ini yaitu :

1. Pada variabel harga diharapkan pihak Umah Batik Sayu Wiwit Banyuwangi bisa memberikan harga yang terjaangkau lagi, sehingga konsumen lebih loyal lagi membeli produk kain batik dari Umah Sayu Wiwit Banyuwangi.

2. Pada variabel desain diharapkan pihak Umah Batik Sayu Wiwit Banyuwangi lebih meningkatkan desain yang kreatif dalam proses pembuatan batik, sehingga konsumen lebih tertarik dengan desain yang dimilik Umah Batik Sayu Wiwit Banyuwangi.

3. Pada variabel kualitas produk diharapkan pihak Umah Batik Sayu Wiwit Banyuwangi lebih meningkatkan kualitas produk kain batik yang bagus, sehingga konsumen merasa puas dengan kualitas produk Umah Batik Sayu Wiwit Banyuwangi.

4. Sebagai acuan penelitian selanjutnya dengan tema yang sama, diharapkan dapat menambah variabel yang akan digunakan seperti pengaruh harga,desain serta kualitas produk terhaap kepuasan konsumen umah batik sayu wiwit di banyuwangi.

5. Sebagai acuan penelitian selanjutnya dengan tema yang sama, diharapkan dapat menambah variabel yang akan digunakan seperti promosi, lokasi, brand image dan lainnya, sehingga hasil temuannya lebih baik dalam menjelaskan mengenai loyalitas pelanggan dan faktor-faktor yang mempengaruhinya.

\section{DAFTAR PUSTAKA}

Aaker, David. 2013. Manajemen Ekuitas Merek. Jakarta: Spektrum P. Michael J.

Anggriana, Rina, Nurul Qomariah dan Budi Santoso. Pengaruh Harga, Promosi dan Kualitas Layanan Terhadap Kepuasan Pelanggan Jasa Ojek Online OM-JEK 
Jember. Jurnal Sains Manajemen dan Bisnis Indonesia (JSMBI) Vol. 7 No. 2. 2 Desember 2017. Universitas Muhammdiyah Jember.

Assauri, Sofjan. 2009. Manajemen Pemasaran Konsep Dasar dan Strategi, edisi pertama. Jakarta:Rajagrafindo.

Baker, 2012. Marketing Startegy and Management. Bandung: Alfabet.

Cannon, Joseph P., William D. Perreault Jr. dan Jerome McCarthy. 2008. Alih Bahasa : Diana Angelica dan Ria Cahyani. Dasar-Dasar Pemasaran : Pendekatan Manajerial Global. Buku 2. Edisi 16. Salemba Empat. Jakarta.

Cannon, Joseph P, William D. Perreault, Jerome McCarthy. 2009. Pemasaran Dasar Edisi 16 Pendekatan Manajerial Global Buku 2. Jakarta: Penerbit Salemba Empat.

Ferdinand, Agusty. 2006. Structural Equation Modelling dalam Penelitian Manajemen. Semarang: FE UNDIP.

Gaspersz, Vincent,2005. Total Quality Management. PT Gramedia Pustaka Utama, Jakarta.

G Moore, Franklin dan Thomas E Henderick. 2010. Manajemen Produksi dan Operasi. Jakarta: Erlangga.

Ghozali, Imam. 2005. Aplikasi Analisis Multivariat dengan Program SPSS.Semarang: Badan penerbit Universitas Diponegoro.

Iriyanti, Emik, Nurul Qomariah dan Akhmad Suharto. Pengaruh Harga Kualitas Produk dan Lokasi Terhadap Loyalitas Pelanggan melalui Kepuasan Sebagai Variabel Intervening pada Depot Mie Pangsit Jember". Jurnal Manajemen Bisnis Indonesia Vol 2, No1 Juni 2016. Universitas Muhammdiyah Jember.

Kotler, Philip dan Gary Armstrong. 2009. Prinsip-prinsip Pemasaran, Jilid 1,Edisi Kedelapan,Jakarta,Erlangga.

Kotler, dan Keller. 2009. Manajemen Pemasaran. Jilid I. Edisi ke 13 Jakarta: Erlangga.

Kotler, Amstrong. 2008. Prinsip - Prinsip Pemasaran 2. Edisi kedua belas. Jakarta: Erlangga.

Kotler, Amstrong. 2010. Prinsip-prinsip pemasaran, Edisi keduabelas, Jilid 1. Jakarta: Erlangga.

Kotler, Philip dan Gary Armstrong, 2006, Prinsip-prinsip Pemasaran, Jilid 2, Edisi Kedelapan,Jakarta,Erlangga. 
Kotler, Philip dan Amstrong. Gary. 2008. Prinsip-Prinsip Pemasaran (Jilid 2). Erlangga : Jakarta.

Kotler, Philip 2005, “manajmen pemasaran’’ Jilid I dan II, PT. Indeks, Jakarta.

Lupiyoadi, Rambat dan A.Hamdani, 2012, Manajemen Pemasaran Jasa, Salemba 4, Jakarta.

Mayasari, dwi Septiani suwarni. 2011. Pengaruh Kualitas Produk dan Harga Terhadap Loyalitas Melalui Kepuasan Konsumen Studi Kasus Kartu Perdana IM3 di Fakultas Negeri Malang. Jurnal ekonomi bisnis. Vol.16 No. 1, maret Tahun 2011.

Nasution, M 2005, “Total Quality Management”, PT Gramedia Pustaka Utama: Jakarta.

Oktaviani, Rani. 2016. Pengaruh kualitas produk, kepercayaan merek, dan kepuasan konsumen terhadap loyalitas merek (Studi pada Mahasiswa Fakultas Ilmu Keolahragaan Universitas Negeri Yogyakarta Pengguna Minuman Isotonik Merek Mizone). Skripsi. Fakultas Ekonomi. Universitas Negeri Yogyakarta.

Pranata, Hery. 2017. Pengaruh Harga, Desain Serta Fitur Terhadap Kepuasan Konsumen dan Loyalitas Merek Produk Smartphone Merek Samsung Pada Konsumen di Wilayah Tegalboto Jember. Skripsi. Fakultas Ekonomi an Bisnis. Universitas Negeri Jember.

Qomariah, Nurul. 2016. Marketing Adactive Strategy. Jember. Cahaya Ilmu.

Swasta, Basu dan Irawan, 2005, Asas-asas Marketing, Liberty, Yogyakarta.

Sugiyono. 2008. Metode Penelitian Bisnis. Bandung: CV. Alfabeta.

Sugiyono. 2010. Metode Penelitian Pendidikan Pendekatan Kuantitatif, kualitatif, dan $R \& D$. Bandung: Alfabeta.

Sugiyono. 2012. Metode Penelitian Bisnis. Bandung : Alfabeta.

Stringer, Michael \& C. Dennis. 2015. Chilled foods. England: TJI Digital Padstow, comwal.

Tjiptono, Fandy. 2015. Strategi Pemasaran. Yogyakarta: CV Andi. Offset.

Tristiana, Ani. 2016. Pengaruh Kualitas Produk dan Harga Terhadap KepuasanKonsumen Sepeda Motor Honda Vario. Jurnal Ilmu dan Riset Manajemen .Volume 5 (6), Juni 2016. Sekolah Tinggi Ilmu Ekonomi Indonesia (STIESIA).

Tajab, Umpu Malik. 2017. Pengaruh Kualitas Produk, Harga dan Desain Produk Sepeda Motor Honda Scoopy fi Dengan Kepuasaan Konsumen (studi kasus pt tunas dwipa matra raden intan Bandar lampung). Skripsi. Fakultas Ekonomi. Universitas Lampung. 
Yus, R Hardjadinata , 2013, Manajemen Produksi dan Operasi, Dialog Bandung Agustina,Astri.http://ekonomi.inilah.com/read/1839270/URLTEENAGE. Diunduh pada tanggal 15 desember 2017.

https://www.voaindonesia.com/a/batik-jawa-timur-mendunia-melalui-kekayaan-motifdan-pewarna-alam/2469846.html. Diunduh pada tanggal 11 juli 2018. 